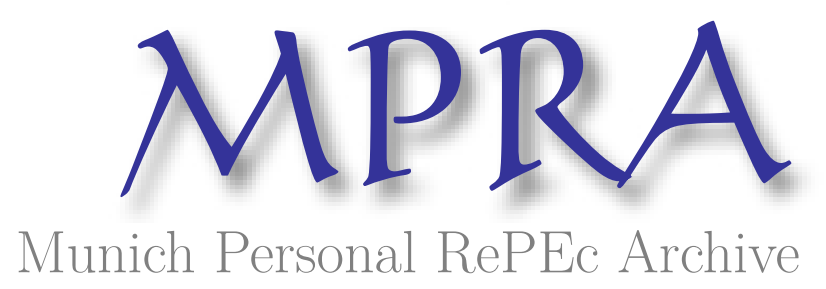

\title{
Look who's talking: the impacts of the intrahousehold allocation of mobile phones on agricultural prices
}

Lee, Kyeong Ho and Bellemare, Marc F.

Duke University

19 May 2012

Online at https://mpra.ub.uni-muenchen.de/38908/

MPRA Paper No. 38908, posted 21 May 2012 03:02 UTC 


\title{
Look Who's Talking: The Impacts of the Intrahousehold Allocation of Mobile Phones on Agricultural Prices
}

\author{
Kyeong Ho Lee $e^{\dagger}$ \\ Marc F. Bellemare
}

May 19, 2012

\begin{abstract}
Using data from the Philippines, we study the impact of mobile phones on the prices agricultural producers receive for their cash crop. We first look at the impact on price of mobile phone ownership at the household level. Because this masks a considerable amount of heterogeneity, we then look at the impact on price of the intrahousehold allocation of mobile phones. We find that whether the household owns a mobile phone has no impact on price, but whether a farmer or his spouse own a mobile phone is associated with a 5- to 7-percent increase in price.

Keywords: Agricultural Prices, Mobile Phones, Intrahousehold Allocations, Asia, Philippines

JEL Classification Codes: O13, O33, Q11, Q12
\end{abstract}

\footnotetext{
* We thank Rufo Guillermo, Ditas Ramos, Hircoles Corpus, and Ate Clarence for field research assistance. We are grateful to the Philippine Rice Research Institute for logistical support and the Robertson Scholars Program for financial support. Lastly, we thank two anonymous reviewers, Rosemary Fernholz, Amar Hamoudi, and Linda Raftree for helpful comments and suggestions. All remaining errors are ours.

${ }^{\dagger}$ Project Affiliate, Innovations for Poverty Action, Ulaanbaatar, Mongolia and Former Student, Duke University, Box 90312, Durham, NC 27707-0312, lee.kyeongho@gmail.com.

* Corresponding Author and Assistant Professor, Duke University, Box 90312, Durham, NC 27708-0312, marc.bellemare@duke.edu.
} 


\section{Introduction}

The last decade has seen a rapid growth in the number of mobile phones in developing countries. In 1998, according to the International Telecommunication Union (ITU), one individual in 20 subscribed to mobile phones throughout the world. By 2008, that figure had climbed to almost 12 individuals in 20, with developing countries accounting for almost two thirds of mobile-phone use in 2008 compared with less than half in 2002 (ITU, 2009). As a result, the mobile phone is the most rapidly adopted information communication technology (ICT) in the world.

Over the same time period, mobile phones have spread from urban centres to rural areas as well as from the wealthy to the poor in developing countries (Aker and Mbiti, 2010). Moreover, mobile phones are often the only form of telecommunication to be found in rural areas of developing countries (Donner, 2008). Many individuals and households throughout the developing world have thus "leapfrogged" fixed-line telephone technology altogether in order to directly adopt mobile phone technology.

For individuals and households in rural areas of developing countries, for whom the cultivation and subsequent sale of cash crops is often the only source of cash, the adoption of mobile phone technology can entail a reduction in the transaction (that is, information and search) costs associated with finding the trading partner who will purchase one's crop at the highest price. ${ }^{1}$ By reducing the transaction costs associated with the sale of cash crops - farmers who own mobile phones can simply call potential trading partners instead of taking the time to visit them - mobile phone technology can stimulate market activity, especially in areas with poor transportation infrastructure. This leads to more efficient allocations of resources, which in turn allows economic policies to have their intended effects by reducing price distortions (de Janvry et al., 1991). 
For these reasons, concurrently with the spread of mobile phones throughout rural areas of the developing world, there has been a sharp increase in the number of development agencies and organisations as well as in the scale of development projects and programs encouraging the adoption of mobile phones. For example, the Millennium Village Project (MVP) introduced village mobile phones to monitor health indicators (MVP, 2010). Likewise, Grameen claims that "mobile phones not only create a new business opportunity for the poor, [they] also bring access to information, market, health and other services to the remote rural areas" (Grameen, 2007). Lastly, new nongovernmental organisations (NGOs) such as MobileActive have emerged in response to the presumed beneficial impact of mobile phones on the poor, and the United Nations encourages the use of mobile phones as a means of achieving the Millennium Development Goals.

Despite the hype surrounding mobile phone technology, however, the evidence on the impacts of mobile phones on the welfare of individuals and households is relatively scant. Within that literature, a good amount of attention has been devoted to the impact of mobile phone technology on traders and consumers (Overa, 2006; Aker, 2010). Indeed, although Commander et al. (2011) find that the use of ICT - defined as anything from some Internet and email use to the use of centrally automated and integrated production processes - increases firm productivity in Brazil and India, few studies have assessed the impact of mobile phones on producers. $^{2}$

We study the impact of mobile phone technology on agricultural producers by directly studying the relationship between mobile phone ownership and the price received by producers for a cash crop. More importantly, we study the impact of mobile phones at both the household and intrahousehold levels, first by controlling for whether the household owns a mobile phone, 
and then by controlling for who within the household owns a mobile phone. We do so because even though the information obtained by way of a mobile phone is a club good, ${ }^{3}$ a mobile phone is itself a private good. As such, it may not always be possible for a farmer whose household owns a mobile phone to use the mobile phone to look for a better price if, for example, the mobile phone is owned by one of the farmer's children - in this context, this also includes the adult children of the parents who still live at home - who does not accompany the farmer in his dealings with traders.

Using survey data on farmers from three districts in Nueva Ecija, a landlocked province of the Philippines, we estimate the determinants of prices received by farmers for onions, the main cash crop in the survey area. Our findings suggest that mobile phone ownership at the household level has no statistically significant impact on the prices received by farmers. Rather, they suggest that it is the intrahousehold allocation of mobile phones that matters in determining the prices received by farmers for their onions. Our core empirical results indicate that mobile phone ownership by a farmer is associated with a 6-percent increase in the price received by the farmer for his cash crop. When removing price outliers, our results indicate that mobile phone ownership by the farmer's spouse is associated with a 7-percent increase in the price received by the farmer for his cash crop. Ownership of a mobile phone by the farmer's children, however, appears to be negatively associated with the price received by the farmer for his cash crop, although this relationship is not statistically significant at any of the conventional levels. These findings suggest that the intrahousehold allocation of mobile phones might very well matter for household welfare.

Our approach, however, suffers from two important limitations. First and foremost, our results cannot be argued to be causal. Indeed, no feature of our research design can be exploited 
to successfully establish the causal impact of mobile phones on the prices received by farmers in this context. Our data consist of household survey responses for a cross-section of farmers. As such, what we find is not a causal relationship but an interesting correlation that warrants further investigation aimed at assessing causality. ${ }^{4}$ The novelty of our approach, however, is to link the literature on ICT in developing countries with the literature on intrahousehold allocations (Thomas, 1990). As such, in suggesting how it is not whether a household owns a mobile phone that matters but rather who within the household owns a mobile phone, our empirical results suggest that in order to maximise policy effectiveness, development policy makers need to look beyond simple household-level mobile phone ownership. ${ }^{5}$

Second, our empirical results rely on a relatively small sample of 95 observations stratified by mobile phone ownership at the household level. Although the households in our sample were randomly selected from within each stratum (that is, owners and non-owners of mobile phones) in each district, the relatively small size of our sample could undermine statistical confidence in our results. To remedy this, we conduct robustness checks in which the standard errors are bootstrapped in the online appendix, finding no qualitative differences as regards the impact of mobile phones between these and our core results, which instead rely on robust standard errors.

\section{Background}

This study is based on a survey of 95 agricultural households in three districts (that is, barangays) surrounding San Jose, the second largest city in the Nueva Ecija province of the Philippines. ${ }^{6}$ Located in the Central Luzon region of the country, Nueva Ecija is a landlocked province whose population attained 1.8 million people in 2007 according to National Statistical Office estimates (NSO, 2010). Nueva Ecija is also one of the largest rice- and onion-producing 
provinces in the Philippines. As of 2002, it had the highest number of farms and the largest farmed area in Central Luzon, with 119,148 farms spread out across 196,390 hectares of land for an average of 1.65 hectares per farm (NSO, 2010).

Although rice is the most important crop in Nueva Ecija, the analysis in this paper focuses on yellow onions for three reasons. First, unlike rice, which is a subsistence crop, yellow onions remain the most important cash crop in Nueva Ecija and around San Jose. Second, the price of onions is more volatile than the price of rice, which makes for an environment in which those with better access to price information are more likely to have a significant advantage over those who do not. ${ }^{7}$ Third, onions are a perishable crop, and a consistent finding in the literature on the impact of ICT in developing countries is that mobile phones have a greater positive impact on perishable than on non-perishable crops, since many farmers in developing countries lack the storage capacity required to smooth out price fluctuations (Deaton and Laroque, 1996; Overa, 2006; Jensen, 2007; Muto and Yamano, 2009; Aker, 2010). Consequently, those with better access to price information are more likely to do significantly better in this environment.

Farmers can sell their onions to traders or agents. Traders often hire agents to buy onions from farmers. Traders sell onions wholesale across different areas within a province or across provinces. For rice, farmers have the additional option of selling their rice directly to "buying stations," or small warehouses mostly located in downtown San Jose. Onion sellers do not have that option and sell directly to agents or traders who come into town instead. Although the Walrasian model of economic theory posits that a given good will be traded at a unique price in equilibrium, there exist significant transaction costs for both sellers and buyers of onions, which wedge themselves between the market price of onions and the effective sales price received by onion sellers (that is, farmers) and the effective purchases price paid by onion buyers (that is, 
traders or agents). As such, a farmer and an agent or trader transacting together form a bilateral monopoly, in which case the price at which onions will be transacted upon need not correspond to the perfectly competitive price of neoclassical economic theory. Indeed, the relative bargaining power of each party, the likelihood that a farmer and an agent will transact with each other in the future, reputational concerns, and other considerations may push the realised price away from that predicted by the Walrasian model (Fafchamps, 2004). ${ }^{8}$

Lastly, we note that in the present context, a mobile phone is simply a device that allows one to make and receive calls as well as to send and receive text messages. The mobile phones used by our survey respondents are thus a far cry from the smart phones most readers will be familiar with. In other words, our survey respondents do not use mobile phone applications to track commodity prices. Rather, if they use their mobile phones to obtain better prices, they use them to talk to or exchange text messages with agents and traders.

\section{Data and Descriptive Statistics}

Table 1 presents a list of the variables used in this paper along with a detailed description of each variable. ${ }^{9}$ Table 2 presents sample-weighted descriptive statistics. As regards our dependent variable, farmers receive on average a price of US $\$ 0.20$ per $\mathrm{kg}$ of onions. ${ }^{10,11}$ The overwhelming majority of farmers in the sample are male, with less than 2 percent of farmers being female. The average farmer is 46 years old and has completed about eight years of education, which suggests that the average farmer in the data has received some secondary education.

Before turning to household level variables, we note that Stinner (1977) reports that the statistical definition of household in the Philippines is 
"a group of people who sleep in the same dwelling unit and have common arrangements for the preparation and consumption of food. (...) In most cases, a household consists of a related family group. (...) In most cases, a household may be taken to be the entire group of persons who customarily sleep in one dwelling unit. An exception, however, is that of two or more distinct family groups with independent eating arrangements who share one dwelling unit only for economy or for lack of housing facilities in the district."

Stinner also reports an average within-household ratio of nuclear family members to extended family members equal to 0.91 in rural areas, and that 92.1 percent of rural households in the Philippines consist of fewer than two nuclear families living under the same roof. Given the foregoing, it seems safe to assume that the children in our data are those of the farmer and his spouse and that those children live under the same roof as their parents.

The average household is composed of about four individuals, about one third of whom are dependents. ${ }^{12}$ The average household cultivates 0.43 hectares of land. This includes land devoted to onions, rice, and other crops. In the Philippines, "smallholders" are defined as households who farm less than two hectares, which means that the average household in the data is a smallholder. The majority of farmers in the data cultivate either onions or rice but rarely both within a given season. In our data, the average farmer dedicates almost the entirety of his landholdings -0.42 hectares out of 0.43 hectares, or 98 percent of his landholdings - to onion cultivation. The average household had an income of about US $\$ 1,120$ from non-onion related sources between January and May in 2010.

Four different types of land ownership are observed in the data. A little over half the farmers in our sample own all of the land they farm. About a third of farmers, however, cultivate some land under a fixed-rent or share tenancy agreement. ${ }^{13}$ Likewise, a little under 15 percent of farmers own some mortgaged land, whereas about 3 percent are amortising owners of some land. 
Almost half of the farmers in the data report that they are members of agricultural organisations, which we use here as crude measures of what Godquin and Quisumbing (2008) refer to as formal social capital (by opposition to informal social capital, which they defines as a respondent's trust-based network) in the rural Philippines. These organisations can potentially give farmers access to cheaper inputs and loans at a lower interest rate than those acquired individually. Sometimes, the only form of formal loans is through group members. Rural banks tend to give loans to groups which are then responsible for disbursing smaller loans to their members. Organisations like farmer field schools can also give access to more advanced farming practice methods. Among the farmers surveyed, about one in 20 belongs to a cooperative, almost one in four belongs to an irrigator association, a little over one in ten belongs to farmer field school, and about one in 20 belongs to either a cooperative or to some other farmer association. Lastly, the farmers in our sample are distributed almost uniformly across districts.

Turning to our variables of interest, almost half of all households in the data own a mobile phone, a figure that is consistent with the regional statistics discussed above. In the full sample of all households in the data, the farmer owns a mobile phone in 28 percent of cases, his wife owns a mobile phone in 13 percent of cases, and at least one of his children owns a mobile phone in 11 percent of cases, respectively.

\section{Empirical Framework}

In order to study the impact of mobile phones on the output prices received by farmers in our data, we focus on two regressions of interest. The first regression is designed to study the impact of mobile phone ownership at the household level on price, such that

$$
\ln y_{i}=\alpha_{1}+\beta_{1} x_{i}+\delta_{1} d_{j}+\gamma_{1 h} m_{h i}+\epsilon_{1 i}
$$


where $y_{i}$ is the price received by farmer $i$ for his output, $x_{i}$ is a vector of household characteristics, $d_{j}$ is a vector of district dummies, $m_{h i}$ is a variable equal to one if anyone within household $i$ owns a mobile phone and equal to zero otherwise, and $\epsilon_{1 i}$ is an error term with mean zero.

The second regression is designed to study the impact of mobile phone ownership by controlling for the intrahousehold distribution of mobile phones, such that

$$
\ln y_{i}=\alpha_{2}+\beta_{2} x_{i}+\delta_{2} d_{j}+\gamma_{2 f} m_{f i}+\gamma_{2 s} m_{s i}+\gamma_{2 c} m_{c i}+\epsilon_{2 i}
$$

where $y_{i}, x_{i}$, and $d_{j}$ are defined as in equation $1 ; m_{f i}, m_{s i}$, and $m_{c i}$ are dummy variables for whether the farmer, his spouse, or any of his children owns a mobile phone; and $\epsilon_{2 i}$ is an error term with mean zero.

In both equations 1 and 2, the dependent variable is the natural logarithm of the price received by the farmer rather than the price level. We take the logarithm of the dependent variable because prices are typically log-normally distributed, that is, the logarithm follows a normal distribution. ${ }^{14}$

Not all the farmers in our data sold their onion harvest in a single transaction. Some of them reported two $(n=23)$ or three $(n=4)$ transactions. This unfortunately does not allow using farmer fixed effects given that individual characteristics - including mobile phone ownership at both the household and individual levels - would collapse into the farmer fixed effect. For those farmers who reported more than one transaction, we simply use the average onion price received as the dependent variable. 
Both equations 1 and 2 are estimated by ordinary least squares (OLS) with robust standard errors. ${ }^{15}$ In equation 1 , the hypothesis test of interest is such that $H_{0}: \gamma_{1 h}=0$ versus $H_{A}: \gamma_{1 h} \neq 0$. In this case, a rejection of the null hypothesis in favour of $\gamma_{1}>0$ would suggest that the presence of a mobile phone within the household is associated with significantly higher received onion prices. Likewise, in equation 2, the hypothesis tests of interest are such that (i) $H_{0}: \gamma_{2 f}=0$ versus $H_{A}: \gamma_{2 f} \neq 0$, (ii) $H_{0}: \gamma_{2 s}=0$ versus $H_{A}: \gamma_{2 s} \neq 0$, and (iii) $H_{0}: \gamma_{2 c}=0$ versus $H_{A}: \gamma_{2 c} \neq 0$. In this case, a rejection of any of the null hypotheses in favour of $\gamma_{2}>0$ would suggest that individual mobile phone ownership is associated with significantly higher onion prices.

Lastly, in the online appendix, we also estimate a specification in which we control for household-level mobile phone ownership on the basis of observables. We do this in order to assess the robustness of our finding at the household level. In the first stage of this specification, we estimate the determinants of mobile phone ownership at the household-level by estimating a probit regression. In the second stage of this specification, we estimate the determinants of onion prices, replacing the dummy variable controlling for the presence of a mobile phone at the household level with the predicted probability of mobile phone ownership obtained from the first-stage probit instead of actual mobile phone ownership as a regressor. In what follows, we refer to this as the two-stage specification.

\section{Estimation Results and Discussion}

Before proceeding with the parametric empirical analysis discussed in the previous section, it may be helpful to begin the discussion of our empirical results with some simple nonparametric evidence so as to assess whether there exist unconditional relationships between the variables of interest (that is, mobile phone ownership at the household and the intrahousehold distribution of 
mobile phones conditional on mobile phone ownership) and the outcome variable (that is, the prices received by the farmers for their onions). ${ }^{16}$

\subsection{Nonparametric Analysis}

Figures 1 and 2 in the online appendix present kernel density estimates of the distribution of the logarithm of the onion price. Table 3 presents mean onion prices by mobile phone ownership regime at the household level and, conditional on the household owning a mobile phone, at the intrahousehold level. In this case, note that the households who own a mobile phone do not receive a price that is significantly different than the price received by the households who do not own a mobile phone. Rather, it is the intrahousehold distribution of mobile phones that appears to matter: the households in which the farmer himself owns a mobile phone appear to receive a significantly higher price for their onions than the households in which the farmer does not own a mobile phone. This finding is reversed when looking at whether the farmer's children own a mobile phone.

\subsection{Parametric Results}

The empirical results in table 3 do not control for confounding factors. Consequently, table 4 presents estimation results for the determinants of the prices received by respondents controlling for farmer and household characteristics as well as for whether the household owns a mobile phone. The specifications in table 4 progressively build up the regression by focusing first on farmer and household characteristics (column 1), then by adding the farmers' ownership status on the majority of his landholdings (column 2), and finally by adding crude measures of social capital and district fixed effects (column 3). 
In this case, the household's income and its landholdings are associated with higher onion prices, whereas the size of the households' cultivated area devoted to onions is associated with lower onion prices. While the former results are unsurprising - higher incomes and larger landholdings are likely correlated with a better bargaining position - the latter finding is prima facie puzzling. Because the vast majority of farmers in the data tend to sell their onion harvest in one transaction given the fixed transaction costs incurred for each transaction, however, it is likely that the more onions a farmer shows up with at a meeting with a trader, the more likely he is to have to accept giving a price discount to the person he transacts with. This is perhaps because of a lack of storage facilities: given that onions are harvested simultaneously, farmers are likely eager to sell them as soon as possible.

Whether a household owns a mobile phone has no statistically significant impact on the price received by the farmer for his onions. Although one might think that this could be driven by outliers, robustness checks (not shown) indicate that removing these outliers does not change the lack of significance of the household-level mobile phone ownership indicator variable.

We move from the household to the intrahousehold level in table 5 by controlling for who, if anyone, owns a mobile phone within the household. Again, the household's income and its landholdings are associated with higher onion prices, and the size of the households' cultivated area devoted to onions is associated with lower onion prices. What does change in table 5, however, is the impact of mobile phones on the price received by the farmer: in all three specifications in table 5, farmers who own mobile phones appear to receive systematically higher prices for their onions. Computing the average marginal effect of mobile phone ownership in table $5,{ }^{17}$ households for which the farmer owns a mobile phone received prices that were 
respectively 5.3 (column 1), 5.8 (column 2), and 5.8 (column 3) percent higher than households for which the farmer did not own a mobile phone.

Could these findings be driven by the presence of outliers in the dependent variable? Table 6 progressively removes price outliers by keeping only the observations for which the onion price was less than $17 \mathrm{PhP}(\mathrm{n}=94)$, the observations for which the onion price was less than $12 \mathrm{PhP}$ ( $n=90)$, and the observations for which the onion price was less than 11.5 PhP $(n=89)$. In that case, although the intrahousehold allocation of mobile phones still appears to matter in every specification, the impact of mobile phones shifts from whether the farmer owns a mobile phone in table 5 to whether his spouse owns one instead in table 6. We discuss the possible reason for this change in significance in section 5.3.

Computing the average marginal effect of mobile phone ownership in table 6 , households for which the farmer's spouse owns a mobile phone received prices that were respectively 7.3 (column 1), 7.2 (column 2), and 7.2 (column 3) percent higher than households for which the farmer did not own a mobile phone.

Tables 5 and 6 also present the results of four tests of equality of coefficients in order to determine whether the impact of mobile phone ownership is the same across individuals (that is, farmer, spouse, and children) and between pairs of individuals (that is, farmer and spouse, farmer and children, and spouse and children). Generally, the results of these tests indicate that the impact of mobile phone ownership is not equal across individuals. Likewise, mobile phone ownership by the farmer and mobile phone ownership by the farmer's spouse have statistically indistinguishable impacts on onion prices. Both results are true whether one includes price outliers (table 5) or not (table 6). When outliers are included, mobile phone ownership by the 
farmer and mobile phone ownership by the farmer's children have significantly different impacts, but mobile phone ownership by the farmer's children and mobile phone ownership by the farmer's spouse have statistically indistinguishable impacts. These findings are reversed once outliers are excluded. $^{18}$

\subsection{Discussion}

First and foremost, our findings call into question the public good nature of the information obtained by way of mobile phones. While it seems reasonable to assume that one mobile phone per household is sufficient for most social and business purposes, since individuals within the household can take turns using the phone, we find no significant relationship between mobile phone ownership at the household level and prices. This suggests limitations in the extent to which mobile phones are shared within households, even taking into account the fact that a household can own more than one mobile phone. While it is likely that the mobile phone is shared for some purposes such as contacting friends and family, our results indicate that they are not shared for the purposes of searching for better prices. Hence, different individuals within the household seem to own mobile phones for different purposes, and the information obtained by way of mobile phones is less of a public good than is usually assumed.

Second, if indeed it is the case that mobile phone ownership by the spouse has a statistically significant impact but that mobile phone ownership by the farmer himself does not, this could suggest that mobile phones are a source of bargaining power within the households in the data. In cases where the farmer owns the mobile phone, it is possible that the farmer does not share price information with his spouse. Let us take for example a household in which the husband and wife are both responsible for farming but in which only the husband owns a mobile phone. In 
this case, it is clear that the husband has an advantage in searching for potentially higher prices since he can do so more cheaply with his mobile phone. Both the husband and wife, however, have an incentive to control the mobile phone because the person who controls it will have better information about household income. ${ }^{19}$ Farmers may have an incentive to hide a portion of their income so that they have full control of it, especially if the preferences of the spouses are different from each other's, a phenomenon extensively documented in the intrahousehold literature by evaluating impact of exogenous changes in income between men and women on child outcomes and household expenditure patterns (Folbre, 1984; Lundberg et al., 1997; Qian, 2008; Rubalcava et al. 2009). Indeed, Ashraf (2009) notes that in the Philippines, husbands voluntarily hand over their income to their wives who then allocate the household budget in order for husbands to avoid unnecessary personal expenditures, such as those on alcohol. When husbands are given an opportunity to hide their income, however, they do so. There is even a distinct Filipino term - kupit - for this kind of behaviour, wherein a husband "drinks away" his pay on the way home knowing that he will have to turn over his money to his wife otherwise. Ashraf (2009) confirms this behaviour using a randomised research design. Access to a mobile phone for the purposes of price negotiations can thus be a source of control over household income, which is why the spouse's mobile phone may have positive, significant impact that it has in table 6. This is all the more likely given that the marginal impact of mobile phone ownership by the farmer's spouse is economically, if not statistically, significantly higher than the marginal impact of mobile phone ownership by the farmer himself.

Third, our empirical results raise the question of why mobile phones are not reallocated from the children to the parents within the households who own a mobile phone. ${ }^{20}$ Indeed, if a farmer is aware that a mobile phone within his household will only be useful in securing better prices 
for his crops if he is the owner of that phone, why would he not claim the phone for himself? This reasoning, while intuitively appealing, implicitly assumes that higher onion prices automatically mean higher welfare for the household or the individual farmer. It could very well be the case, however, that one of the farmer's children has a mobile phone because she can make a better use of it in terms of welfare. As such, our finding should not be interpreted as evidence of anomalous behaviour on the part of the households we study.

Lastly, our findings indicate that it may be advantageous for "ICT for development"-type (ICTD) interventions to target specific household members so as to maximise impact. Depending on the outcome, technologies can have heterogeneous effects on the household. In San Jose, Nueva Ecija, it is well-known that farmers have a competitive advantage in negotiating prices and generally have a more extensive buyer network, so it is no surprise that in our data, farmer ownership of mobile phones is associated with a higher sales price. In this context, there does not appear to be high educational or income barriers to using mobile phones since they are simple to use and relatively cheap, and the use of mobile phones is widespread even in rural areas. With more complex ICTD tools such as mobile phone applications, however, it may be important to target not just farmers, but those farmers can use the technology most effectively to maximise the outcome of interest.

A good example in which the intrahousehold allocation of technology matters in conjunction with education is with the International Rice Research Institute's Nutrient Manager for Rice Text (NMRice Txt) program in the Philippines. A free service, NMRice Txt helps farmers calculate the optimal fertiliser needs based on a set of responses that users enter about their plot characteristics corresponding to questions asked by an automated voice over the mobile phone (Nelson, 2010). When the service was tested in the provinces of Iloilo and Isabela, farmers who 
had previously owned mobile phones and who knew how to make and receive calls and send and receive text messages struggled in using the new service, even with the aid of three video presentations on how to use the software, lectures by trained agricultural extension workers, visual demonstrations, and automated questions adjusted to the local dialect of the provinces. When farmers were asked if they would use the service in the future, most of them responded that they would have their children, who are more tech-savvy, use NMRice Txt (Nelson, 2010).

There is thus some anecdotal evidence suggesting that mobile phone-based initiatives can be adopted more effectively if farmers are taught the intuition behind new farming practices while more tech-savvy members of the household are targeted for use. Labonne and Chase (2009), for example, find a significant correlation between educational attainment of the oldest child in the household and household mobile phone ownership. Likewise, the estimation results in appendix table A1 online indicate that in our data, more educated farmers are more likely to have access to a mobile phone within their household. Both these findings suggest that the presence of educated individuals in the household drives technology adoption in the household, similarly to how Basu and Foster (1998) show how the presence of a literate individual in a given household creates a positive externality for the illiterate members of the household, who become "proximate literates" as a result.

\section{Conclusion}

There exist important but distinct literatures respectively on the impacts of information communication technology on rural markets (Overa, 2006; Jensen, 2007; Donner, 2009; Labonne and Chase, 2009; Muto and Yamano, 2009; Aker, 2010; Aker and Mbiti, 2010; Klonner and Nolen, 2010) and on the impacts of intrahousehold control of income and bargaining power 
(Thomas, 1990; Lundberg et al., 1997; Qian, 2008; Ashraf, 2009; Rubalcava et al., 2009). We link these two literatures by studying the hitherto unexplored impacts of the intrahousehold allocation of information communication technology. ${ }^{21}$

Specifically, we study the impacts of mobile phone ownership at both the household and intrahousehold levels on the prices by agricultural producers. Using survey data on a crosssection of onion farmers in the Nueva Ecija province of the Philippines, we find that the presence of a mobile phone at the household level appears to have no statistically significant impact on the price received by a farmer for his onions, but whether the farmer himself owns a mobile phone is associated with a 6-percent increase in the price received for his onions.

Given the considerable amount of empirical evidence against the unitary household model (Alderman et al., 1995), according to which the individuals that compose a household can be aggregated into a single, stylised "individual" represented by a single set of preferences, there are good a priori reasons to believe that who controls a given technology within the household may matter. Our empirical finding - mobile phones appear to have a positive impact on prices, but only when the farmer or his spouse own the mobile phone within a household - calls into question ICTD-type policy interventions designed around the allocation of mobile phones at the household level (or worse, at the village level, as in the Grameen village mobile phones case). This is all the more important given the growing number of ICTD efforts.

Given the nature of our data, however, our empirical findings cannot be argued to be causal. That is, we cannot exploit a specific feature of research design or a specific variable to establish the potential causal relationship that flows from mobile phones to agricultural prices. Rather, we find an interesting correlation between the intrahousehold allocation of mobile phones that appears too important for policy makers and researchers to ignore. Moreover, given our small 
sample size and the fact that our data only focuses on one region of the Philippines, our results have little external validity. But given the growing importance of ICT in developing countries and in development policy, this correlation warrants further investigation so as to determine whether there is indeed a causal relationship between mobile phones and agricultural prices, and whether such a causal relationship holds broadly across developing countries.

${ }^{1}$ While we apply our argument to net seller households (that is, households who sell more of a given cash crop than they buy of it), a similar argument can be made for net buyer households (that is, households who buy more of a given cash crop than they buy of it), for whom the adoption of mobile phone technology can entail a reduction in the transaction costs associated with finding the trading partner who will sell a crop at the lowest price. See Key et al. (2000), Fafchamps and Hill (2005), and Bellemare and Barrett (2006) for empirical investigations of how transaction costs can impede market participation.

${ }^{2}$ One exception is the paper by Klonner and Nolen (2010), who look at the impact of mobile phone technology on rural labour markets and find that employment increases substantially once a given area receives network coverage. Similarly, Chowdhury (2006) finds that access to landline phones increase rural factor market (land and labour) participation by about 14 percent in Bangladesh.

3 Although information is nonrival (that is, an individual's consumption of a given piece of information does not preclude others from doing so), it is excludable (that is, an individual can preclude others from consuming a given piece of information by keeping it secret). It is in this sense that it is a club good. 
${ }^{4}$ We also estimate a two-stage specification conceptually close to a propensity score matching (PSM) model to assess the robustness of our finding at the household level. Using this PSM-type approach does not allow making a causal statement, but it offers additional evidence in favour of our finding that the presence of a mobile phone at the household level does not affect the price received by the farmer.

${ }^{5}$ The findings in this paper could thus be extended to those of other studies. For example, Jensen (2007) looks at the impact of mobile phones on the prices obtained by fishermen in India, but he does not look at who else might own a mobile phone within fishing households. Muto and Yamano (2009) look at whether household-level mobile phone ownership increases market participation, but they do not look at who owns a mobile phone within the household. Aker (2010) focuses on the impact of mobile phones on the prices obtained by traders in Niger, but she also does not look at who else might own a mobile phone within trader households. Futch and McIntosh (2009), for their part, look at the impact of village-level mobile phones in Rwanda on a number of measures, which neglects the impact of the allocation of mobile phones both within the village and within households.

${ }^{6}$ The smallest administrative region in the Philippines, a barangay refers to a ward within a municipality.

${ }^{7}$ Annual farmgate price series obtained from the Bureau of Agricultural Statistics of the Philippines indicate that the coefficient of variation (that is, standard deviation divided by mean) was 0.46 for dry paddy and 0.68 for yellow onions for the period 1990-2004 (that is, the period for which annual farmgate prices are available for both commodities). Similarly, the standard deviation of the dry paddy price series was equal to $1.77 \mathrm{PhP}$, whereas the standard deviation of the yellow onions price series was equal to $6.05 \mathrm{PhP}$. 
${ }^{8}$ Likewise, it is in principle possible that a farmer might decide to sell his onions to the trader who offers the highest price on the basis of a telephone conversation and that the trader subsequently decides to hold up the farmer by reneging on his promised price once the farmer has incurred the transaction cost of meeting with the trader. Repeated interactions and reputational concerns should minimise the number of such occurrences, however.

${ }^{9}$ The online appendix discusses sampling and the probability weights used in the empirical work below.

${ }^{10}$ This price figure may seem low to those familiar with the context. Informal conversations with farmers suggest that in 2010, the year the data were collected, onion prices were indeed low compared to previous years.

${ }^{11}$ At the time of writing, US $\$ 1 \approx \mathrm{PhP} 46$.

${ }^{12}$ A household's dependency ratio is equal to the proportion of individuals younger than 15 and older than 64 years of age within the household. Thus, while household size is a rough measure of labour quantity within the household, the dependency ratio is an equally rough measure of labour quality within the household.

${ }^{13}$ Because there was only one case of share tenancy in the data, we lump sharecroppers and fixed renters into a single "tenant" category. The four categories of land ownership do not sum up to one due to the ambiguous ownership status of some plots of land.

${ }^{14}$ During preliminary work, we also conducted robustness checks in which we used the level instead of the logarithm of the price received by the farmer. The results of those robustness checks (not shown) were qualitatively similar to the ones presented in this paper. 
${ }^{15}$ We conduct robustness checks with bootstrapped standard errors in the online appendix. The results of those robustness checks are not qualitatively different from those with robust standard errors as regards the impact of mobile phones on prices.

${ }^{16}$ Although the means-comparison tests we present as part of our nonparametric results compare actual parameters, we use the term "nonparametric" in the sense that the evidence in this section is free from distributional assumptions.

${ }^{17}$ The average marginal effects reported in this paper were calculated using the formula derived by Kennedy (1981) to calculate the marginal impact of a dummy variable in a semilogarithmic equation. Kennedy's method improved upon earlier derivations by Halvorsen and Palmquist (1980).

${ }^{18}$ An anonymous reviewer suggested we define a dummy variable equal to one if either the farmer or his spouse owns a mobile phone and use this instead of two separate mobile phone ownership dummies for the farmer and his spouse. As it turns out, in the specifications in which we use this new variable instead of two separate variables (not shown), the coefficient on the dummy variable for combined mobile phone ownership is not statistically significant. This unsurprising given that this new variable combines two variables, one of which has a statistically insignificant coefficient estimate. It thus looks as though it is individual (farmer or spouse) rather than parental mobile phone ownership that matters in this context.

${ }^{19}$ Eder (2006) notes that women's relationship to household assets is indirect in the Philippines a woman's access to household assets is mediated through her husband's. Eder also notes that though there is a common conception that women in the Philippines prevail in roundabout ways over men when it comes to economic decisions within the household, his experience is that women often prevail explicitly and directly. Schmeer (2005) documents the fact that married 
women use their control over economic resources to increase household spending on food in the Philippines.

${ }^{20}$ Similarly, Udry’s (1996) finding about agricultural productivity differentials between men and women within the same households in Burkina Faso raises the question of why households do not reallocate plots from women to men.

${ }^{21}$ This is not to say that the intrahousehold allocation of technology broadly defined has not been studied. See Peterman et al. (2011) for an extensive review of the empirical evidence on the gender differences in agricultural inputs, technology, and services in developing countries. 


\section{References}

Aker, J. (2010) Information from markets near and far: mobile phones and agricultural markets in Niger. American Economic Journal: Applied Economics 2(3), pp. 46-59.

Aker, J. and Mbiti, I. (2010) Mobile phones and economic development in Africa. Journal of Economic Perspectives 24(3), pp. 207-232.

Alderman, H., Chiappori, P.-A., Haddad, L., Hoddinott, J. and Kanbur R. (1995) Unitary versus collective models of the household: is it time to shift the burden of the proof? World Bank Research Observer 10(1), pp. 1-19.

Ashraf, N. (2009) Spousal control and intrahousehold decision making: an experimental study in the Philippines. American Economic Review 99(4), pp. 1245-1277.

Basu, K. and Foster, J.E. (1998) On measuring literacy. Economic Journal 108(451), pp. 17331749 .

Bellemare, M.F. and Barrett, C.B. (2006) An ordered tobit model of market participation: evidence from Kenya and Ethiopia. American Journal of Agricultural Economics 88(2), pp. 324-337.

Chowdhury, S.K. (2006) Access to a telephone and factor market participation of rural households in Bangladesh. Journal of Agricultural Economics 57(3), pp. 563-576.

Commander, S., Harrison, R. and Menezes-Filho N. (2011) ICT and productivity in developing countries: new firm-level evidence from Brazil and India. Review of Economics and Statistics 93(2), pp. 528-541. 
Deaton, A. and Laroque, G. (1996) Competitive storage and commodity price dynamics. Journal of Political Economy 104(5), pp. 896-923.

de Janvry, A., Fafchamps, M. and Sadoulet E. (1991) Peasant household behaviour with missing markets: some paradoxes explained. Economic Journal 101(409), pp. 1400-1417.

Donner, J. (2009) Mobile-based livelihood services in Africa: pilots and early deployments, in: M. Fernandez-Ardevol and A. Ros Hijar (eds) Communication Technologies in Latin America and Africa: A Multidisciplinary Perspective (Barcelona: IN3), pp. 37-58.

Eder, J.F. (2006) Gender relations and household economic planning in the rural Philippines. Journal of Asian Studies 37(3), pp. 397-413.

Fafchamps, M. (2004) Market institutions in sub-Saharan Africa: theory and evidence (Cambridge, MA: MIT Press).

Fafchamps, M. and Vargas Hill, R. (2005) Selling at the farmgate or travelling to market. American Journal of Agricultural Economics 87(3), pp. 717-734.

Folbre, N. (1984) Household production in the Philippines: a non-neoclassical approach. Economic Development and Cultural Change 32(2), pp. 303-330.

Futch, M., and McIntosh, C.T. (2009) Tracking the introduction of the village phone product in Rwanda. Information Technologies \& International Development 5(3), pp. 54-81.

Godquin, M. and Quisumbing, A. (2008) Separate but equal? The gendered nature of social capital in rural philippine communities. Journal of International Development 20(1), pp. 1333. 
Grameen Bank (2011) Village phones, http://www.grameeninfo.org/index.php?option=com_content\&task=view\&id=681\&Itemid=676 accessed May 17, 2011.

Halvorsen, R. and Palmquist, R. (1980) The interpretation of dummy variables in semilogarithmic equations. American Economic Review 70(3), pp. 474-475.

International Telecommunications Union (2009) The world in 2009: ICT facts and figures, http://www.itu.int/ITU-D/ict/material/Telecom09_flyer.pdf accessed May 17, 2011.

Jensen, R. (2007) The digital provide: information (technology) market performance, and welfare in the south Indian fisheries sector. Quarterly Journal of Economics 122(3), pp. 879924.

Kennedy, P.E. (1981) Estimation with correctly interpreted dummy variables in semilogarithmic equations. American Economic Review 71(4), pp. 801.

Key, N., Janvry, A. and Sadoulet, E. (2000) Transactions costs and agricultural household supply response. American Journal of Agricultural Economics 82(2), pp. 245-259.

Klonner, S. and Nolen, P.J. (2010) Cell phones and rural labour markets: evidence from South Africa. Working Paper, Department of Economics, University of Essex.

Labonne, J. and Chase, R. (2009) The power of information: the impact of mobile phones on farmers' welfare in the Philippines. Social Development Department, Policy Research Working Paper \#4996, The World Bank.

Lundberg, S., Pollak, R. and Wales, T. (1997) Do husbands and wives pool resources? Evidence from the UK child benefit. Journal of Human Resources 32(3), pp. 463-480. 
Millennium Villages Project (2010) Achieving the goals: progress to date, http://www.millenniumvillages.org/progress/ accessed May 17, 2011

Muto, M. and Yamano, T. (2009) The Impact of Mobile Phone Coverage Expansion on Market Participation: Panel Data Evidence from Uganda. World Development 37(12), pp. 1887-96.

National Statistical Office (2006) 2003 Family income and expenditure survey. (Manila: National Statistical Office).

National Statistical Office (2010) Agriculture sector in Central Luzon, http://www.census.gov.ph/data/sectordata/ag0412403.htm accessed May 17, 2011.

Nelson, K. (2010) Extension goes mobile. Rice Today 9(4), pp. 29-30.

Overa, R. (2006) Networks, distance, and trust: telecommunications development and changing trading practices in Ghana. World Development 34(7), pp. 1301-15.

Peterman, A., Behrman, J. and Quisumbing, A. (2011) A review of empirical evidence on gender differences in nonland agricultural inputs, technology, and services in developing countries. Discussion Paper 00975, Poverty, Health, and Nutrition Division, International Food Policy Research Institute.

Qian, N. (2008) Missing women and the price of tea in China: the effect of sex-specific earnings on sex imbalance. Quarterly Journal of Economics 123(3), pp. 1251-1285.

Rubalcava, L., Teruel, G. and Thomas, D. (2009) Investments, time preferences, and public transfers paid to women. Economic Development and Cultural Change 57(3), pp. 507-538.

Schmeer, K.K. (2005) Married women's resource position and household food expenditures in Cebu, Philippines. Journal of Marriage and Family 67(2), pp. 399-409. 
Stinner, W.F. (1977) Urbanization and household structure in the Philippines. Journal of Marriage and Family 39(2), pp. 377-385.

Thomas, Duncan (1990) Intrahousehold resource allocation: an inferential approach. Journal of Human Resources 25(4), pp. 635-664.

Udry, Christopher (1996) Gender, agricultural production, and the theory of the household. Journal of Political Economy 104(5), pp. 1010-1046. 
Table 1. Variable Descriptions

\begin{tabular}{|c|c|}
\hline Variable & Description \\
\hline Price of Onions & $\begin{array}{l}\text { Average price received by the farmer for his or her onions, in } \\
\text { Philippine pesos }(\mathrm{PhP})\end{array}$ \\
\hline Farmer Age & Farmer's age, in completed years \\
\hline Farmer Female & $=1$ if the farmer is female; $=0$ otherwise \\
\hline Farmer Single & $=1$ if the farmer is single; $=0$ otherwise \\
\hline Farmer Education & Farmer's education, in completed years \\
\hline Household Size & Number of individuals in the household \\
\hline Household Dependency Ratio & $\begin{array}{l}\text { Number of individuals younger than } 15 \text { and older than } 65 \text { in } \\
\text { the household divided by the number of individuals in the } \\
\text { household }\end{array}$ \\
\hline Household Income & $\begin{array}{l}\text { Household income, in 1,000s of PhP. This includes from non- } \\
\text { onion farm-related income; income derived from livestock } \\
\text { and poultry; income from off-farm labour; income from self- } \\
\text { employment; income from remittances; and other sources of } \\
\text { income }\end{array}$ \\
\hline Household Landholdings & Total amount of land owned by the household in hectares \\
\hline Household Cultivated Area & $\begin{array}{l}\text { Total amount of land under onion cultivation by the } \\
\text { household, in hectares }\end{array}$ \\
\hline Amortising Owner & $\begin{array}{l}=1 \text { if the farmer is an amortising owner on some of his or her } \\
\text { lands; }=0 \text { otherwise }\end{array}$ \\
\hline Mortgage Owner & $\begin{array}{l}=1 \text { if the farmer is a mortgage owner on some of his or her } \\
\text { lands; }=0 \text { otherwise }\end{array}$ \\
\hline Tenant & $\begin{array}{l}=1 \text { if the farmer is a fixed rent or share tenant on some of his } \\
\text { or her lands; }=0 \text { otherwise }\end{array}$ \\
\hline Owner & $\begin{array}{l}=1 \text { if the farmer is the owner of all his or her lands } ;=0 \\
\text { otherwise, the omitted category }\end{array}$ \\
\hline Farmer Field School & $\begin{array}{l}=1 \text { if the farmer is a member of a farmer field school; }=0 \\
\text { otherwise }\end{array}$ \\
\hline Cooperative & $=1$ if the farmer is a member of a cooperative $;=0$ otherwise \\
\hline Irrigator Association & $\begin{array}{l}=1 \text { if the farmer is a member of an irrigation association; }=0 \\
\text { otherwise }\end{array}$ \\
\hline Other Farmer Association & $\begin{array}{l}=1 \text { if the farmer is a member of a farmers' association; }=0 \\
\text { otherwise }\end{array}$ \\
\hline Household Mobile Phone & $=1$ if the household owns a mobile phone; $=0$ otherwise \\
\hline Farmer Mobile Phone & $=1$ if the farmer owns a mobile phone; $=0$ otherwise \\
\hline Spouse Mobile Phone & $\begin{array}{l}=1 \text { if the farmer's spouse owns a mobile phone } ;=0 \\
\text { otherwise }\end{array}$ \\
\hline Children Mobile Phone & $\begin{array}{l}=1 \text { if any of the farmer's children own a mobile phone } ;=0 \\
\text { otherwise }\end{array}$ \\
\hline District 1 & $=1$ if the household lives in district $1 ;=0$ otherwise \\
\hline District 2 & $=1$ if the household lives in district $2 ;=0$ otherwise \\
\hline District 3 & $=1$ if the household lives in district $3 ;=0$ otherwise \\
\hline
\end{tabular}


Table 2. Descriptive Statistics (n=95)

\begin{tabular}{|c|c|}
\hline Variable & $\begin{array}{c}\text { Mean } \\
\text { (Std. Err.) }\end{array}$ \\
\hline Price of Onions $(\mathrm{PhP})$ & $\begin{array}{c}9.393 \\
(0.133)\end{array}$ \\
\hline Farmer Age (Years) & $\begin{array}{l}45.721 \\
(1.513)\end{array}$ \\
\hline Farmer Female Dummy & $\begin{array}{c}0.015 \\
(0.011)\end{array}$ \\
\hline Farmer Single Dummy & $\begin{array}{c}0.054 \\
(0.023)\end{array}$ \\
\hline Farmer Education (Completed Years) & $\begin{array}{c}8.109 \\
(0.319)\end{array}$ \\
\hline Household Size (Individuals) & $\begin{array}{c}4.075 \\
(0.162)\end{array}$ \\
\hline Household Dependency Ratio & $\begin{array}{c}0.352 \\
(0.032)\end{array}$ \\
\hline Household Income (1000s PhP) & $\begin{array}{l}51.460 \\
(9.150)\end{array}$ \\
\hline Household Landholdings (Hectares) & $\begin{array}{c}0.430 \\
(0.040)\end{array}$ \\
\hline Household Cultivated Area (Hectares) & $\begin{array}{c}0.420 \\
(0.030)\end{array}$ \\
\hline Amortising Owner Dummy & $\begin{array}{c}0.031 \\
(0.019)\end{array}$ \\
\hline Mortgage Owner Dummy & $\begin{array}{c}0.141 \\
(0.038)\end{array}$ \\
\hline Fixed Rent or Share Tenant Dummy & $\begin{array}{c}0.300 \\
(0.050)\end{array}$ \\
\hline Farmer Field School Dummy & $\begin{array}{c}0.111 \\
(0.036)\end{array}$ \\
\hline Cooperative Dummy & $\begin{array}{c}0.070 \\
(0.028)\end{array}$ \\
\hline Irrigator Association Dummy & $\begin{array}{c}0.235 \\
(0.047)\end{array}$ \\
\hline Farmer Association Dummy & $\begin{array}{c}0.048 \\
(0.025)\end{array}$ \\
\hline Household Cell Phone Dummy & $\begin{array}{c}0.470 \\
(0.050)\end{array}$ \\
\hline Farmer Cell Phone Dummy & $\begin{array}{c}0.276 \\
(0.043)\end{array}$ \\
\hline Spouse Cell Phone Dummy & $\begin{array}{c}0.134 \\
(0.031)\end{array}$ \\
\hline & 31 \\
\hline
\end{tabular}


Children Cell Phone Dummy

0.112

(0.028)

District 1 Dummy

District 2 Dummy

District 3 Dummy
0.369

(0.053)

0.280

(0.049)

0.351

(0.054) 
Table 3. Mean Onion Price Comparisons by Mobile Phone Ownership (n=95)

\begin{tabular}{|c|c|c|c|}
\hline \multirow[t]{3}{*}{ Unit } & Mean & Mean & Significance \\
\hline & \multicolumn{2}{|c|}{ Log of Onion Price } & \\
\hline & $\begin{array}{c}\text { Owns Cell } \\
\text { Phone }\end{array}$ & $\begin{array}{c}\text { Does Not Own Cell } \\
\text { Phone }\end{array}$ & \\
\hline \multirow[t]{2}{*}{ Household } & 2.240 & 2.220 & \\
\hline & $(0.020)$ & $(0.020)$ & \\
\hline \multirow[t]{2}{*}{ Farmer } & 2.270 & 2.210 & $* *$ \\
\hline & $(0.030)$ & $(0.020)$ & \\
\hline \multirow[t]{2}{*}{ Spouse } & 2.260 & 2.230 & \\
\hline & $(0.030)$ & $(0.020)$ & \\
\hline \multirow[t]{2}{*}{ Children } & 2.190 & 2.240 & $*$ \\
\hline & $(0.030)$ & $(0.020)$ & \\
\hline
\end{tabular}

Note: $* * * \mathrm{p}<0.01, * * \mathrm{p}<0.05,{ }^{*} \mathrm{p}<0.1$. Standard errors in parentheses. 
Table 4. OLS Estimation Results for the Determinants of Onion Prices

\begin{tabular}{|c|c|c|c|}
\hline Variable & (1) & (2) & (3) \\
\hline \multicolumn{4}{|c|}{ Dependent Variable: Log of Onion Price } \\
\hline \multirow[t]{2}{*}{ Farmer Age } & -0.001 & -0.001 & 0.000 \\
\hline & $(0.001)$ & $(0.001)$ & $(0.002)$ \\
\hline \multirow[t]{2}{*}{ Farmer Female } & -0.010 & -0.008 & -0.058 \\
\hline & $(0.058)$ & $(0.063)$ & $(0.072)$ \\
\hline \multirow[t]{2}{*}{ Farmer Single } & 0.075 & 0.075 & 0.054 \\
\hline & $(0.114)$ & $(0.120)$ & $(0.134)$ \\
\hline \multirow[t]{2}{*}{ Farmer Education } & 0.001 & 0.002 & -0.001 \\
\hline & $(0.006)$ & $(0.007)$ & $(0.007)$ \\
\hline \multirow[t]{2}{*}{ Household Size } & -0.001 & 0.000 & -0.005 \\
\hline & $(0.008)$ & $(0.008)$ & $(0.011)$ \\
\hline \multirow[t]{2}{*}{ Household Dependency Ratio } & 0.027 & 0.027 & 0.012 \\
\hline & $(0.047)$ & $(0.048)$ & $(0.051)$ \\
\hline \multirow[t]{2}{*}{ Household Income } & $0.000 * *$ & $0.000 * *$ & $0.000 * * *$ \\
\hline & $(0.000)$ & $(0.000)$ & $(0.000)$ \\
\hline \multirow[t]{2}{*}{ Household Landholdings } & $0.435 * * *$ & $0.440 * * *$ & $0.415 * *$ \\
\hline & $(0.116)$ & $(0.122)$ & $(0.171)$ \\
\hline \multirow[t]{2}{*}{ Household Onion Area } & $-0.492 * * *$ & $-0.496 * * *$ & $-0.428 * *$ \\
\hline & $(0.118)$ & $(0.121)$ & $(0.181)$ \\
\hline \multirow[t]{2}{*}{ Amortising Owner } & & 0.027 & 0.011 \\
\hline & & $(0.049)$ & $(0.053)$ \\
\hline \multirow[t]{2}{*}{ Mortgage Owner } & & 0.008 & -0.001 \\
\hline & & $(0.037)$ & $(0.037)$ \\
\hline \multirow[t]{2}{*}{ Tenant } & & 0.001 & -0.008 \\
\hline & & $(0.041)$ & $(0.040)$ \\
\hline \multirow[t]{2}{*}{ Farmer Field School } & & & 0.026 \\
\hline & & & $(0.034)$ \\
\hline \multirow[t]{2}{*}{ Cooperative } & & & 0.069 \\
\hline & & & $(0.048)$ \\
\hline \multirow[t]{2}{*}{ Irrigator Association } & & & -0.048 \\
\hline & & & $(0.036)$ \\
\hline \multirow[t]{2}{*}{ Farmer Association } & & & 0.040 \\
\hline & & & $(0.064)$ \\
\hline Household Mobile Phone & 0.012 & 0.011 & 0.024 \\
\hline
\end{tabular}




\begin{tabular}{lccc} 
& $(0.028)$ & $(0.029)$ & $(0.030)$ \\
District 2 & & & 0.078 \\
& & & $(0.058)$ \\
District 3 & & & $0.074 * *$ \\
& & & $(0.037)$ \\
Constant & $2.238^{* * *}$ & $2.235^{* * *}$ & $2.191 * * *$ \\
& $(0.115)$ & $(0.129)$ & $(0.139)$ \\
& & & \\
Observations & 95 & 95 & 95 \\
R-squared & 0.147 & 0.148 & 0.207 \\
\hline Note: $* * * \mathrm{p}<0.01, * * \mathrm{p}<0.05, * \mathrm{p}<0.1$. Huber-White robust standard errors in parentheses.
\end{tabular}


Table 5. OLS Estimation Results for the Determinants of Onion Prices Controlling for the Allocation of Mobile Phones

\begin{tabular}{|c|c|c|c|}
\hline Variable & (1) & (2) & (3) \\
\hline \multicolumn{4}{|c|}{ Dependent Variable: Log of Onion Price } \\
\hline \multirow[t]{2}{*}{ Farmer Age } & 0.000 & 0.000 & 0.001 \\
\hline & $(0.001)$ & $(0.001)$ & $(0.002)$ \\
\hline \multirow[t]{2}{*}{ Farmer Female } & 0.009 & 0.012 & -0.043 \\
\hline & $(0.065)$ & $(0.070)$ & $(0.081)$ \\
\hline \multirow[t]{2}{*}{ Farmer Single } & 0.066 & 0.062 & 0.043 \\
\hline & $(0.111)$ & $(0.120)$ & $(0.136)$ \\
\hline \multirow[t]{2}{*}{ Farmer Education } & -0.001 & -0.001 & -0.003 \\
\hline & $(0.007)$ & $(0.007)$ & $(0.007)$ \\
\hline \multirow[t]{2}{*}{ Household Size } & 0.003 & 0.003 & -0.003 \\
\hline & $(0.008)$ & $(0.008)$ & $(0.011)$ \\
\hline \multirow[t]{2}{*}{ Household Dependency Ratio } & 0.008 & 0.007 & -0.007 \\
\hline & $(0.050)$ & $(0.052)$ & $(0.057)$ \\
\hline \multirow[t]{2}{*}{ Household Income } & $0.000 *$ & $0.000 *$ & $0.000 * *$ \\
\hline & $(0.000)$ & $(0.000)$ & $(0.000)$ \\
\hline \multirow[t]{2}{*}{ Household Landholdings } & $0.490 * * *$ & $0.494 * * *$ & $0.454 * *$ \\
\hline & $(0.125)$ & $(0.131)$ & $(0.186)$ \\
\hline \multirow[t]{2}{*}{ Household Cultivated Area } & $-0.551 * * *$ & $-0.556^{* * *}$ & $-0.469 * *$ \\
\hline & $(0.126)$ & $(0.130)$ & $(0.197)$ \\
\hline \multirow[t]{2}{*}{ Amortising Owner } & & 0.043 & 0.021 \\
\hline & & $(0.055)$ & $(0.058)$ \\
\hline \multirow[t]{2}{*}{ Mortgage Owner } & & -0.002 & -0.012 \\
\hline & & $(0.036)$ & $(0.035)$ \\
\hline \multirow[t]{2}{*}{ Tenant } & & 0.016 & 0.006 \\
\hline & & $(0.040)$ & $(0.040)$ \\
\hline \multirow[t]{2}{*}{ Farmer Field School } & & & 0.033 \\
\hline & & & $(0.037)$ \\
\hline \multirow[t]{2}{*}{ Cooperative } & & & 0.059 \\
\hline & & & $(0.052)$ \\
\hline \multirow[t]{2}{*}{ Irrigator Association } & & & -0.050 \\
\hline & & & $(0.037)$ \\
\hline \multirow[t]{2}{*}{ Farmer Association } & & & 0.023 \\
\hline & & & $(0.058)$ \\
\hline Farmer Mobile Phone & $0.052 *$ & $0.056^{*}$ & $0.057 *$ \\
\hline
\end{tabular}




\begin{tabular}{|c|c|c|c|}
\hline \multirow{3}{*}{ Spouse Mobile Phone } & $(0.031)$ & $(0.031)$ & $(0.031)$ \\
\hline & 0.037 & 0.036 & 0.058 \\
\hline & $(0.035)$ & $(0.036)$ & $(0.036)$ \\
\hline \multirow[t]{2}{*}{ Children Mobile Phone } & -0.045 & -0.051 & -0.041 \\
\hline & $(0.037)$ & $(0.040)$ & $(0.046)$ \\
\hline \multirow[t]{2}{*}{ District 2} & & & 0.088 \\
\hline & & & $(0.062)$ \\
\hline \multirow[t]{2}{*}{ District 3} & & & $0.076^{*}$ \\
\hline & & & $(0.039)$ \\
\hline \multirow{2}{*}{ Constant } & $2.225^{* * * *}$ & $2.207 * * *$ & $2.161 * * *$ \\
\hline & $(0.116)$ & $(0.129)$ & $(0.137)$ \\
\hline Observations & 95 & 95 & 95 \\
\hline p-value $($ Farmer $=$ Spouse $=$ Children $)$ & 0.08 & 0.06 & 0.11 \\
\hline p-value $($ Farmer $=$ Spouse $)$ & 0.74 & 0.68 & 0.98 \\
\hline $\mathrm{p}$-value $($ Farmer $=$ Children $)$ & 0.03 & 0.02 & 0.04 \\
\hline $\mathrm{p}$-value $($ Spouse $=$ Children $)$ & 0.12 & 0.11 & 0.11 \\
\hline $\mathrm{R}$-squared & 0.187 & 0.193 & 0.252 \\
\hline
\end{tabular}


Table 6. Robustness Checks on the OLS Estimation Results for the Determinants of Onion Prices Controlling for the Intrahousehold Allocation of Mobile Phones

\begin{tabular}{|c|c|c|c|}
\hline Variable & (1) & $(2)$ & (3) \\
\hline \multicolumn{4}{|c|}{ Dependent Variable: Log of Onion Price } \\
\hline \multirow[t]{2}{*}{ Farmer Age } & 0.002 & $0.003 * *$ & $0.003 * *$ \\
\hline & $(0.001)$ & $(0.001)$ & $(0.001)$ \\
\hline \multirow[t]{2}{*}{ Farmer Female } & -0.011 & -0.005 & -0.006 \\
\hline & $(0.097)$ & $(0.080)$ & $(0.081)$ \\
\hline \multirow[t]{2}{*}{ Farmer Single } & -0.078 & -0.048 & -0.049 \\
\hline & $(0.090)$ & $(0.079)$ & $(0.079)$ \\
\hline \multirow[t]{2}{*}{ Farmer Education } & -0.002 & 0.001 & 0.001 \\
\hline & $(0.006)$ & $(0.005)$ & $(0.005)$ \\
\hline \multirow[t]{2}{*}{ Household Size } & -0.010 & -0.009 & -0.009 \\
\hline & $(0.009)$ & $(0.009)$ & $(0.009)$ \\
\hline \multirow[t]{2}{*}{ Household Dependency Ratio } & -0.020 & -0.019 & -0.020 \\
\hline & $(0.053)$ & $(0.052)$ & $(0.053)$ \\
\hline \multirow[t]{2}{*}{ Household Income } & $0.000 * * *$ & $0.000 * * *$ & $0.000 * *$ \\
\hline & $(0.000)$ & $(0.000)$ & $(0.000)$ \\
\hline \multirow[t]{2}{*}{ Household Landholdings } & $0.313 * *$ & $0.297^{*}$ & $0.297^{*}$ \\
\hline & $(0.144)$ & $(0.150)$ & $(0.150)$ \\
\hline \multirow[t]{2}{*}{ Household Cultivated Area } & $-0.318 * *$ & $-0.280 *$ & $-0.280 *$ \\
\hline & $(0.154)$ & $(0.161)$ & $(0.161)$ \\
\hline \multirow[t]{2}{*}{ Amortising Owner } & 0.001 & 0.028 & 0.027 \\
\hline & $(0.054)$ & $(0.049)$ & $(0.051)$ \\
\hline \multirow[t]{2}{*}{ Mortgage Owner } & 0.010 & 0.023 & 0.023 \\
\hline & $(0.031)$ & $(0.031)$ & $(0.031)$ \\
\hline \multirow[t]{2}{*}{ Tenant } & 0.030 & 0.031 & 0.031 \\
\hline & $(0.032)$ & $(0.032)$ & $(0.032)$ \\
\hline \multirow[t]{2}{*}{ Farmer Field School } & 0.037 & 0.022 & 0.022 \\
\hline & $(0.037)$ & $(0.033)$ & $(0.033)$ \\
\hline \multirow[t]{2}{*}{ Cooperative } & 0.036 & 0.024 & 0.024 \\
\hline & $(0.047)$ & $(0.047)$ & $(0.047)$ \\
\hline \multirow[t]{2}{*}{ Irrigator Association } & -0.052 & $-0.059 *$ & $-0.059 *$ \\
\hline & $(0.035)$ & $(0.033)$ & $(0.034)$ \\
\hline \multirow[t]{2}{*}{ Farmer Association } & 0.005 & -0.003 & -0.003 \\
\hline & $(0.055)$ & $(0.040)$ & $(0.040)$ \\
\hline
\end{tabular}




$\begin{array}{lccc}\text { Farmer Mobile Phone } & 0.050^{*} & 0.039 & 0.039 \\ & (0.029) & (0.028) & (0.028) \\ \text { Spouse Mobile Phone } & 0.071^{* *} & 0.070^{* *} & 0.070^{* *} \\ & (0.034) & (0.033) & (0.033) \\ \text { Children Mobile Phone } & -0.049 & -0.035 & -0.035 \\ & (0.043) & (0.042) & (0.042) \\ \text { District 2 } & 0.126^{* *} & 0.103^{* *} & 0.105^{* *} \\ & (0.050) & (0.047) & (0.051) \\ \text { District 3 } & 0.088^{* *} & 0.095^{* *} & 0.096^{* *} \\ & (0.038) & (0.038) & (0.039) \\ \text { Constant } & 2.092^{* * *} & 2.016^{* * *} & 2.016^{* * *} \\ & (0.120) & (0.095) & (0.096)\end{array}$

$\begin{array}{lccc}\text { Observations } & 94 & 90 & 89 \\ \text { p-value }(\text { Farmer }=\text { Spouse }=\text { Children }) & 0.06 & 0.14 & 0.14 \\ \text { p-value }(\text { Farmer }=\text { Spouse }) & 0.63 & 0.42 & 0.42 \\ \text { p-value }(\text { Farmer }=\text { Children }) & 0.04 & 0.11 & 0.11 \\ \text { p-value }(\text { Spouse }=\text { Children }) & 0.03 & 0.05 & 0.05 \\ \text { R-squared } & 0.272 & 0.309 & 0.285\end{array}$

Note: ${ }^{* * *} \mathrm{p}<0.01,{ }^{* *} \mathrm{p}<0.05, * \mathrm{p}<0.1$. Huber-White robust standard errors in parentheses. The number of observations diminishes so as to progressively eliminate possible dependent-variable outliers. In column 1, one observation, for which the onion price was 17 or greater, was dropped; in column 2 four observations, for which the onion price was 12 or greater, were dropped; and in column 3, one observation, for which the onion price was 11.5 or greater, was dropped. The p-values at the bottom of the table are for tests of the null hypothesis that the relevant coefficients are not statistically different from one another. 


\section{Appendix}

\section{A. Data Sources and Construction}

Survey interviews were conducted between May and June 2010. Because the interviews were conducted two to three months after farmers sold their onions, this paper relies on farmer recall for the relevant information. Because respondents derive the majority of their livelihoods from agriculture, however, their recall of agricultural price information was very good.

Farmer- and household-level data were collected with the help of enumerators trained by the Philippines Rice Research Institute. Within each district, about 30 households were selected. Because there are more mobile phone owners than non-owners in the population, households with no mobile phones were oversampled. In order to bring our sample as close as possible to a random sample, the empirical results in this paper incorporate sample weights computed using the sample and population proportion of household phone ownership and non-ownership. The latter proportions were obtained from the 2003 Family Income and Expenditure Survey (NSO, 2006) for Central Luzon, the region where the province of Nueva Ecija is located. The Family Income and Expenditure Survey finds that 47 percent of the households in Central Luzon own phones. Although this percentage encompasses mobile and fixed-line subscribers, this is a good proxy for mobile phone ownership given that fixed-line subscribers only represented 4.7 percent of households (NSO, 2006). And while mobile phone subscription rates have increased dramatically, fixed-line subscription rates have stagnated in the Philippines. Thus, although this does not allow computing perfect sampling weights, it is the best available data on phone ownership. 
The data are representative of onion farmers in the region we study, i.e., the rural areas around the city of San Jose, Nueva Ecija province, in the Central Luzon region of the Philippines. The data were collected by one of the authors as follows. In each barangay (i.e., district), the author obtained a list of households in the district administration and randomly selected about 40 households from that list. Due to missing observations, the estimation sample includes 36 households from the first district, 29 households from the second district, and 30 households from the third district.

\section{B. Additional Results}

\section{Additional Nonparametric Results}

Figure 1 presents a kernel density estimate of the distribution of the logarithm of the onion price received by each respondent. The value of this exercise is apparent in two ways. First, onion prices appear to be log-normally distributed in our data, which validates our use of the logarithm of onion prices as our dependent variable. Second, further investigation in figure 2, which disaggregates the results in figure 1 by presenting kernel density estimates of the distribution of the logarithm of the onion prices received by mobile phone ownership status, indicates that on average, the households who own a mobile phone appear to receive the same price as the household who do not own a mobile phone. Because of outliers, however, prices appear more volatile for the households who own a mobile phone than for the households who do not due own a mobile phone. It is on the basis of figure 2 that we conduct robustness checks that progressively exclude outliers so as to make sure that our empirical results are not driven by these outliers. 


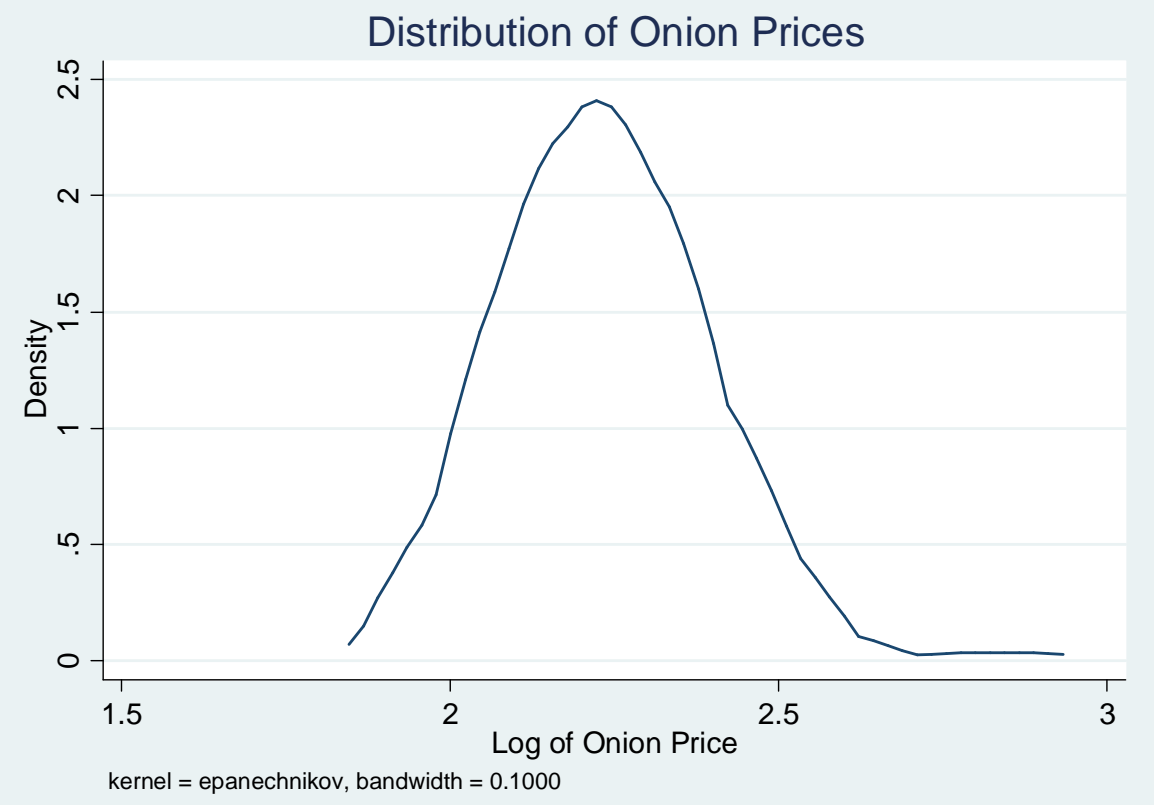

Figure 1. Kernel Density Estimate of the Distribution of Onion Prices with Epanechnikov Kernel and Bandwidth Equal to 0.1.

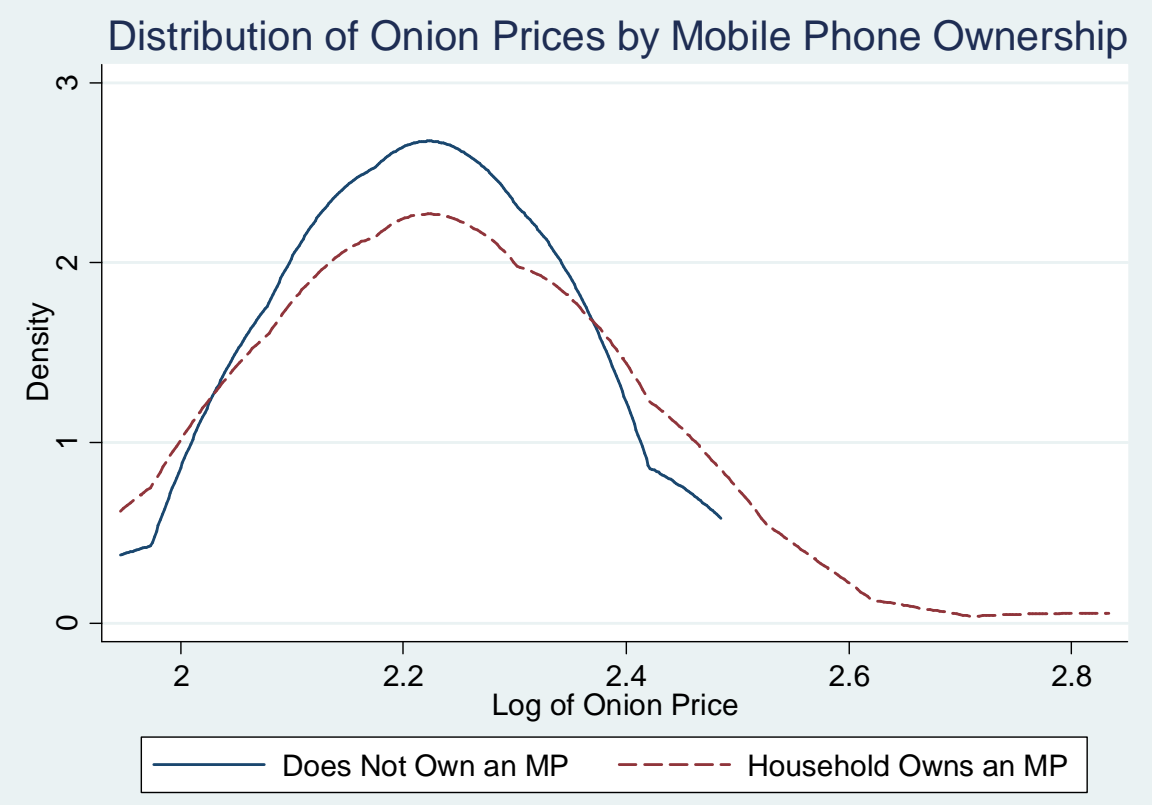

Figure 2. Kernel Density Estimate of the Distribution of Onion Prices by Household Mobile Phone Ownership Status with Epanechnikov Kernel and Bandwidth Equal to 0.1. 


\section{Additional Parametric Results}

For robustness, we estimate a two-stage specification in which we control for each household's propensity to have a mobile phone. Table A1 presents the result of a first-stage probit regression aimed at estimating the determinants of the likelihood that a household will own a mobile phone. ${ }^{1}$ Table A2 presents the result of a second-stage OLS regression in which the household mobile phone indicator variable used in table 4 has been replaced by the predicted probability that a household owns a mobile phone obtained from the probit specification in table $\mathrm{A} 1 .^{2}$ In this case, note that the use of this method does not change the qualitative result that mobile phone ownership at the household level does not seem to be associated with higher prices. When bootstrapping the standard errors (not shown), our results are qualitatively unchanged as regards the impact of mobile phones on prices.

Tables A3 to A5 mirror the results in tables 4 to 6 in the paper, except that the results in tables A3 to A5 use bootstrapped standard errors instead of Huber-White robust standard errors.

\footnotetext{
${ }^{1}$ The indicator variable for whether the household head is female was dropped from the probit regression in appendix table A1 given that it perfectly predicts that a household will own a mobile phone. For the same reason, two observations were dropped in estimating the probit regression appendix table A1.

${ }^{2}$ The probit regression in appendix table A1 made correct predictions in 73 percent of cases. That is, in 69 cases out of 95 , the probit regression in appendix table A1 accurately predicted that a household that did not own a mobile phone would not own a mobile phone or that a household that did own a mobile phone would own a mobile phone.
} 
Table A1. Probit Estimation Results for the Determinant of Mobile Phone Ownership at the Household Level

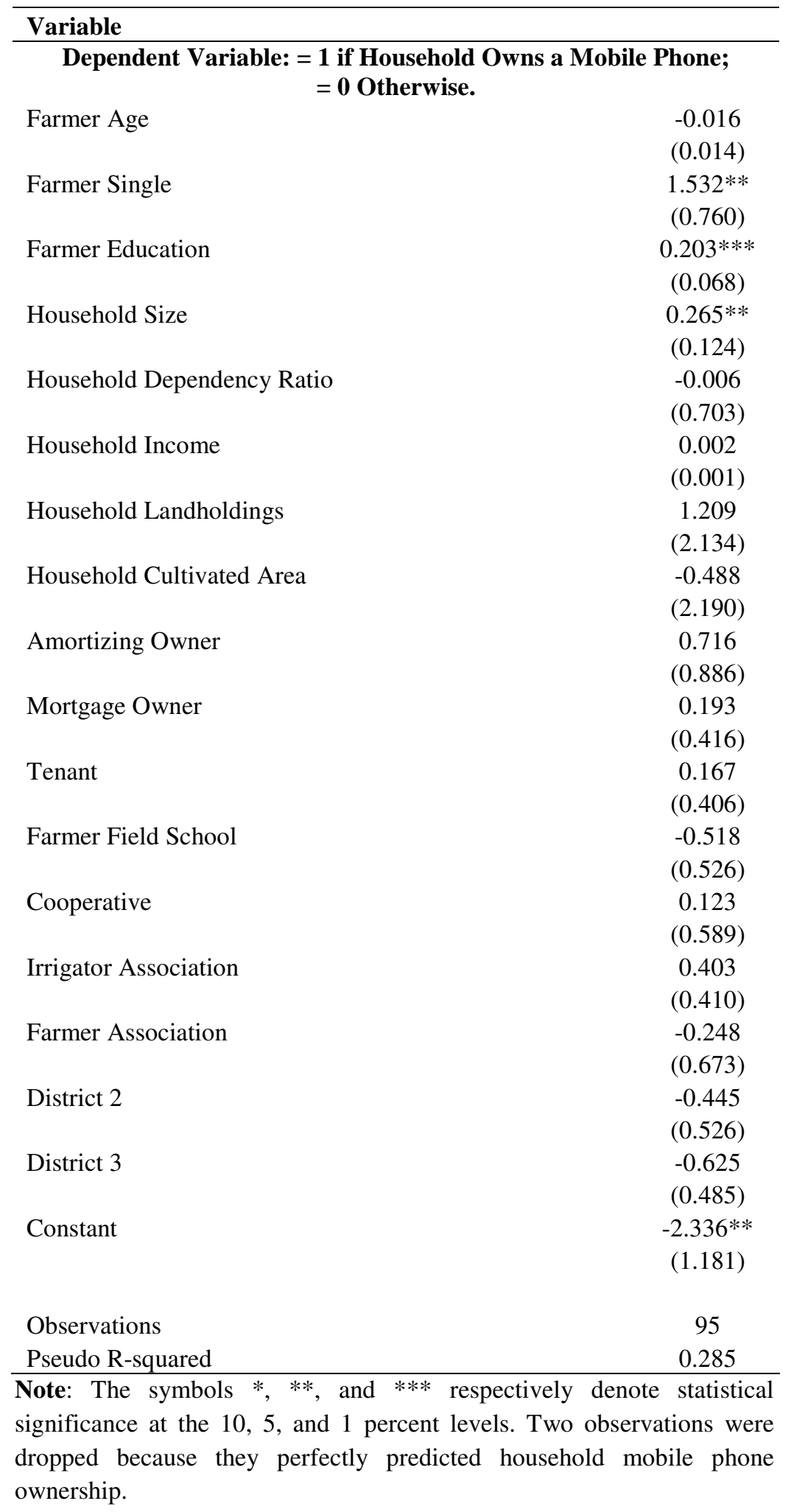


Table A2. OLS Estimation Results for the Determinants of Onion Prices Using the Predicted Probability of Household Mobile Phone Ownership

\begin{tabular}{|c|c|c|c|}
\hline & (1) & $(2)$ & (3) \\
\hline Farmer Age & $\begin{array}{l}-0.001 \\
(0.001)\end{array}$ & $\begin{array}{l}-0.001 \\
(0.001)\end{array}$ & $\begin{array}{c}0.001 \\
(0.002)\end{array}$ \\
\hline Farmer Female & $\begin{array}{l}-0.005 \\
(0.059)\end{array}$ & $\begin{array}{l}-0.001 \\
(0.064)\end{array}$ & $\begin{array}{l}-0.059 \\
(0.077)\end{array}$ \\
\hline Farmer Single & $\begin{array}{c}0.113 \\
(0.120)\end{array}$ & $\begin{array}{l}0.128 \\
(0.126)\end{array}$ & $\begin{array}{l}-0.024 \\
(0.166)\end{array}$ \\
\hline Farmer Education & $\begin{array}{c}0.007 \\
(0.009)\end{array}$ & $\begin{array}{c}0.010 \\
(0.011)\end{array}$ & $\begin{array}{l}-0.012 \\
(0.017)\end{array}$ \\
\hline Household Size & $\begin{array}{c}0.005 \\
(0.009)\end{array}$ & $\begin{array}{c}0.007 \\
(0.010)\end{array}$ & $\begin{array}{l}-0.017 \\
(0.019)\end{array}$ \\
\hline Household Dependency Ratio & $\begin{array}{c}0.022 \\
(0.048)\end{array}$ & $\begin{array}{c}0.022 \\
(0.049)\end{array}$ & $\begin{array}{c}0.015 \\
(0.052)\end{array}$ \\
\hline Household Income & $\begin{array}{c}0.000 * * * \\
(0.000)\end{array}$ & $\begin{array}{c}0.000 * * * \\
(0.000)\end{array}$ & $\begin{array}{c}0.000 \\
(0.000)\end{array}$ \\
\hline Household Landholdings & $\begin{array}{c}0.427 * * * \\
(0.120)\end{array}$ & $\begin{array}{c}0.433^{* * *} \\
(0.125)\end{array}$ & $\begin{array}{l}0.397 * * \\
(0.173)\end{array}$ \\
\hline Household Onion Area & $\begin{array}{c}-0.466 * * * \\
(0.123)\end{array}$ & $\begin{array}{c}-0.464 * * * \\
(0.130)\end{array}$ & $\begin{array}{c}-0.427 * * \\
(0.187)\end{array}$ \\
\hline Amortizing Owner & & $\begin{array}{c}0.057 \\
(0.054)\end{array}$ & $\begin{array}{l}-0.016 \\
(0.059)\end{array}$ \\
\hline Mortgage Owner & & $\begin{array}{c}0.014 \\
(0.038)\end{array}$ & $\begin{array}{l}-0.010 \\
(0.037)\end{array}$ \\
\hline Tenant & & $\begin{array}{c}0.006 \\
(0.041)\end{array}$ & $\begin{array}{l}-0.016 \\
(0.041)\end{array}$ \\
\hline Farmer Field School & & & $\begin{array}{c}0.048 \\
(0.046)\end{array}$ \\
\hline Cooperative & & & $\begin{array}{c}0.060 \\
(0.047)\end{array}$ \\
\hline Irrigator Association & & & $\begin{array}{l}-0.070 \\
(0.050)\end{array}$ \\
\hline Farmer Association & & & $\begin{array}{c}0.053 \\
(0.069)\end{array}$ \\
\hline $\begin{array}{l}\text { Household Mobile Phone } \\
\text { (Predicted) }\end{array}$ & $\begin{array}{l}-0.080 \\
(0.096)\end{array}$ & $\begin{array}{l}-0.117 \\
(0.108)\end{array}$ & $\begin{array}{c}0.191 \\
(0.230)\end{array}$ \\
\hline District 2 & & & $\begin{array}{c}0.098 \\
(0.061)\end{array}$ \\
\hline District 3 & & & $\begin{array}{l}0.109^{*} \\
(0.059)\end{array}$ \\
\hline Constant & $\begin{array}{l}2.212 * * * \\
(0.120)\end{array}$ & $\begin{array}{c}2.192 * * * \\
(0.139)\end{array}$ & $\begin{array}{c}2.221 * * * \\
(0.146)\end{array}$ \\
\hline Observations & 95 & 95 & 95 \\
\hline R-squared & 0.150 & 0.155 & 0.207 \\
\hline
\end{tabular}


Table A3. OLS Estimation Results for the Determinants of Onion Prices

\begin{tabular}{|c|c|c|c|}
\hline Variable & (1) & $(2)$ & (3) \\
\hline \multicolumn{4}{|c|}{ Dependent Variable: Log of Onion Price } \\
\hline \multirow{2}{*}{ Farmer Age } & -0.001 & -0.001 & -0.001 \\
\hline & $(0.001)$ & $(0.001)$ & $(0.002)$ \\
\hline \multirow[t]{2}{*}{ Farmer Female } & -0.013 & -0.013 & -0.058 \\
\hline & $(0.088)$ & $(0.084)$ & $(0.097)$ \\
\hline \multirow[t]{2}{*}{ Farmer Single } & 0.107 & 0.116 & 0.085 \\
\hline & $(0.121)$ & $(0.122)$ & $(0.142)$ \\
\hline \multirow[t]{2}{*}{ Farmer Education } & 0.004 & 0.002 & -0.001 \\
\hline & $(0.005)$ & $(0.006)$ & $(0.006)$ \\
\hline \multirow[t]{2}{*}{ Household Size } & -0.006 & -0.004 & -0.010 \\
\hline & $(0.009)$ & $(0.010)$ & $(0.011)$ \\
\hline \multirow[t]{2}{*}{ Household Dependency Ratio } & 0.019 & 0.016 & -0.002 \\
\hline & $(0.050)$ & $(0.053)$ & $(0.056)$ \\
\hline \multirow[t]{2}{*}{ Household Income } & 0.000 & 0.000 & 0.000 \\
\hline & $(0.000)$ & $(0.000)$ & $(0.000)$ \\
\hline \multirow[t]{2}{*}{ Household Landholdings } & 0.458 & 0.473 & 0.481 \\
\hline & $(0.609)$ & $(0.317)$ & $(0.476)$ \\
\hline \multirow[t]{2}{*}{ Household Onion Area } & -0.534 & $-0.542 *$ & -0.505 \\
\hline & $(0.607)$ & $(0.317)$ & $(0.481)$ \\
\hline \multirow[t]{2}{*}{ Amortizing Owner } & & 0.045 & 0.029 \\
\hline & & $(0.059)$ & $(0.061)$ \\
\hline \multirow[t]{2}{*}{ Mortgage Owner } & & -0.005 & -0.006 \\
\hline & & $(0.045)$ & $(0.046)$ \\
\hline \multirow{2}{*}{ Tenant } & & -0.029 & -0.030 \\
\hline & & $(0.040)$ & $(0.040)$ \\
\hline \multirow[t]{2}{*}{ Farmer Field School } & & & 0.029 \\
\hline & & & $(0.044)$ \\
\hline \multirow[t]{2}{*}{ Cooperative } & & & 0.062 \\
\hline & & & $(0.062)$ \\
\hline \multirow[t]{2}{*}{ Irrigator Association } & & & -0.054 \\
\hline & & & $(0.042)$ \\
\hline \multirow[t]{2}{*}{ Farmer Association } & & & 0.081 \\
\hline & & & $(0.088)$ \\
\hline \multirow[t]{2}{*}{ Household Mobile Phone } & 0.010 & 0.008 & 0.026 \\
\hline & $(0.029)$ & $(0.030)$ & $(0.035)$ \\
\hline \multirow[t]{2}{*}{ District 2} & & & 0.079 \\
\hline & & & $(0.055)$ \\
\hline \multirow[t]{2}{*}{ District 3} & & & $0.084 * *$ \\
\hline & & & $(0.040)$ \\
\hline \multirow[t]{2}{*}{ Constant } & $2.262 * * *$ & $2.287 * * *$ & $2.253 * * *$ \\
\hline & $(0.097)$ & $(0.122)$ & $(0.130)$ \\
\hline Observations & 95 & 95 & 95 \\
\hline Bootstrap Repetitions & 1000 & 1000 & 1000 \\
\hline R-squared & 0.188 & 0.199 & 0.269 \\
\hline
\end{tabular}


Table A4. OLS Estimation Results for the Determinants of Onion Prices Controlling for the Intrahousehold Allocation of Mobile Phones

\begin{tabular}{|c|c|c|c|}
\hline Variable & (1) & $(2)$ & (3) \\
\hline \multicolumn{4}{|c|}{ Dependent Variable: Log of Onion Price } \\
\hline \multirow[t]{2}{*}{ Farmer Age } & -0.000 & -0.000 & 0.000 \\
\hline & $(0.001)$ & $(0.002)$ & $(0.002)$ \\
\hline \multirow[t]{2}{*}{ Farmer Female } & 0.004 & 0.001 & -0.051 \\
\hline & $(0.088)$ & $(0.097)$ & $(0.112)$ \\
\hline \multirow[t]{2}{*}{ Farmer Single } & 0.096 & 0.105 & 0.080 \\
\hline & $(0.118)$ & $(0.129)$ & $(0.142)$ \\
\hline \multirow[t]{2}{*}{ Farmer Education } & 0.000 & -0.000 & -0.003 \\
\hline & $(0.006)$ & $(0.006)$ & $(0.007)$ \\
\hline \multirow[t]{2}{*}{ Household Size } & -0.002 & -0.000 & -0.008 \\
\hline & $(0.009)$ & $(0.010)$ & $(0.012)$ \\
\hline \multirow[t]{2}{*}{ Household Dependency Ratio } & -0.007 & -0.010 & -0.025 \\
\hline & $(0.054)$ & $(0.056)$ & $(0.065)$ \\
\hline \multirow[t]{2}{*}{ Household Income } & 0.000 & 0.000 & 0.000 \\
\hline & $(0.000)$ & $(0.000)$ & $(0.000)$ \\
\hline \multirow[t]{2}{*}{ Household Landholdings } & 0.527 & 0.536 & 0.523 \\
\hline & $(0.448)$ & $(0.429)$ & $(0.665)$ \\
\hline \multirow[t]{2}{*}{ Household Cultivated Area } & -0.601 & -0.606 & -0.545 \\
\hline & $(0.449)$ & $(0.431)$ & $(0.667)$ \\
\hline \multirow[t]{2}{*}{ Amortizing Owner } & & 0.061 & 0.037 \\
\hline & & $(0.065)$ & $(0.066)$ \\
\hline \multirow[t]{2}{*}{ Mortgage Owner } & & -0.017 & -0.020 \\
\hline & & $(0.044)$ & $(0.043)$ \\
\hline \multirow[t]{2}{*}{ Tenant } & & -0.010 & -0.015 \\
\hline & & $(0.041)$ & $(0.042)$ \\
\hline \multirow[t]{2}{*}{ Farmer Field School } & & & 0.041 \\
\hline & & & $(0.049)$ \\
\hline \multirow[t]{2}{*}{ Cooperative } & & & 0.048 \\
\hline & & & $(0.067)$ \\
\hline \multirow[t]{2}{*}{ Irrigator Association } & & & -0.058 \\
\hline & & & $(0.041)$ \\
\hline \multirow[t]{2}{*}{ Farmer Association } & & & 0.055 \\
\hline & & & $(0.079)$ \\
\hline \multirow[t]{2}{*}{ Farmer Mobile Phone } & $0.053^{*}$ & $0.054^{*}$ & $0.053^{*}$ \\
\hline & $(0.032)$ & $(0.032)$ & $(0.032)$ \\
\hline \multirow[t]{2}{*}{ Spouse Mobile Phone } & 0.040 & 0.039 & $0.063^{*}$ \\
\hline & $(0.036)$ & $(0.039)$ & $(0.038)$ \\
\hline \multirow[t]{2}{*}{ Children Mobile Phone } & -0.037 & -0.040 & -0.029 \\
\hline & $(0.040)$ & $(0.044)$ & $(0.054)$ \\
\hline \multirow[t]{2}{*}{ District 2} & & & 0.092 \\
\hline & & & $(0.061)$ \\
\hline \multirow[t]{2}{*}{ District 3} & & & $0.086^{* *}$ \\
\hline & & & $(0.041)$ \\
\hline \multirow[t]{2}{*}{ Constant } & $2.238 * * *$ & $2.246 * * *$ & $2.211^{* * *}$ \\
\hline & $(0.103)$ & $(0.124)$ & $(0.134)$ \\
\hline Observations & 95 & 95 & 95 \\
\hline
\end{tabular}


$\begin{array}{llll}\text { Bootstrap Repetitions } & 1000 & 1000 & 1000\end{array}$

$\begin{array}{lrrr}\text { R-squared } & 0.231 & 0.239 & 0.308\end{array}$

Note: $* * * \mathrm{p}<0.01, * * \mathrm{p}<0.05, * \mathrm{p}<0.1$. Bootstrapped standard errors in parentheses. 
Table A5. Robustness Checks on the OLS Estimation Results for the Determinants of Onion Prices Controlling for the Intrahousehold Allocation of Mobile Phones

\begin{tabular}{|c|c|c|c|}
\hline Variable & (1) & (2) & (3) \\
\hline \multicolumn{4}{|c|}{ Dependent Variable: Log of Onion Price } \\
\hline \multirow[t]{2}{*}{ Farmer Age } & 0.002 & $0.003 * *$ & $0.003^{* *}$ \\
\hline & $(0.002)$ & $(0.001)$ & $(0.001)$ \\
\hline \multirow[t]{2}{*}{ Farmer Female } & -0.014 & -0.015 & -0.016 \\
\hline & $(0.115)$ & $(0.096)$ & $(0.095)$ \\
\hline \multirow[t]{2}{*}{ Farmer Single } & -0.050 & -0.035 & -0.036 \\
\hline & $(0.097)$ & $(0.089)$ & $(0.084)$ \\
\hline \multirow[t]{2}{*}{ Farmer Education } & -0.001 & -0.002 & -0.002 \\
\hline & $(0.006)$ & $(0.005)$ & $(0.005)$ \\
\hline \multirow[t]{2}{*}{ Household Size } & -0.014 & -0.015 & -0.015 \\
\hline & $(0.011)$ & $(0.010)$ & $(0.010)$ \\
\hline \multirow[t]{2}{*}{ Household Dependency Ratio } & -0.047 & -0.043 & -0.043 \\
\hline & $(0.061)$ & $(0.058)$ & $(0.060)$ \\
\hline \multirow[t]{2}{*}{ Household Income } & 0.000 & $0.000^{* *}$ & 0.000 \\
\hline & $(0.000)$ & $(0.000)$ & $(0.000)$ \\
\hline \multirow[t]{2}{*}{ Household Landholdings } & $0.365^{*}$ & $0.388^{* *}$ & $0.388^{*}$ \\
\hline & $(0.196)$ & $(0.197)$ & $(0.205)$ \\
\hline \multirow[t]{2}{*}{ Household Cultivated Area } & $-0.373 *$ & $-0.369^{*}$ & $-0.369^{*}$ \\
\hline & $(0.205)$ & $(0.203)$ & $(0.214)$ \\
\hline \multirow[t]{2}{*}{ Amortizing Owner } & 0.018 & 0.040 & 0.039 \\
\hline & $(0.067)$ & $(0.061)$ & $(0.059)$ \\
\hline \multirow[t]{2}{*}{ Mortgage Owner } & 0.008 & 0.026 & 0.026 \\
\hline & $(0.038)$ & $(0.035)$ & $(0.038)$ \\
\hline \multirow[t]{2}{*}{ Tenant } & 0.014 & 0.022 & 0.022 \\
\hline & $(0.032)$ & $(0.031)$ & $(0.033)$ \\
\hline \multirow[t]{2}{*}{ Farmer Field School } & 0.042 & 0.030 & 0.030 \\
\hline & $(0.052)$ & $(0.044)$ & $(0.045)$ \\
\hline \multirow[t]{2}{*}{ Cooperative } & 0.021 & 0.003 & 0.003 \\
\hline & $(0.062)$ & $(0.060)$ & $(0.060)$ \\
\hline \multirow[t]{2}{*}{ Irrigator Association } & -0.054 & $-0.065^{*}$ & $-0.065^{*}$ \\
\hline & $(0.038)$ & $(0.035)$ & $(0.034)$ \\
\hline \multirow[t]{2}{*}{ Farmer Association } & 0.037 & 0.010 & 0.010 \\
\hline & $(0.080)$ & $(0.050)$ & $(0.049)$ \\
\hline \multirow[t]{2}{*}{ Farmer Mobile Phone } & 0.049 & $0.047 *$ & 0.047 \\
\hline & $(0.031)$ & $(0.028)$ & $(0.029)$ \\
\hline \multirow[t]{2}{*}{ Spouse Mobile Phone } & $0.077 * *$ & $0.082 * *$ & $0.082 * *$ \\
\hline & $(0.038)$ & $(0.036)$ & $(0.036)$ \\
\hline \multirow[t]{2}{*}{ Children Mobile Phone } & -0.041 & -0.027 & -0.027 \\
\hline & $(0.048)$ & $(0.044)$ & $(0.047)$ \\
\hline \multirow[t]{2}{*}{ District 2} & $0.127 * *$ & $0.109^{* *}$ & $0.110^{* *}$ \\
\hline & $(0.052)$ & $(0.048)$ & $(0.049)$ \\
\hline \multirow[t]{2}{*}{ District 3} & $0.095 * *$ & $0.098^{* *}$ & $0.098 * *$ \\
\hline & $(0.039)$ & $(0.038)$ & $(0.038)$ \\
\hline \multirow[t]{2}{*}{ Constant } & $2.125 * * *$ & $2.070 * * *$ & $2.070 * * *$ \\
\hline & $(0.120)$ & $(0.099)$ & $(0.101)$ \\
\hline Observations & 94 & 90 & 89 \\
\hline
\end{tabular}


$\begin{array}{lll}\text { Bootstrap Repetitions } & 1000 & 1000\end{array}$

$\begin{array}{llll}\text { R-squared } & 0.303 & 0.347 & 0.316\end{array}$

Note: $* * * \mathrm{p}<0.01, * * \mathrm{p}<0.05, * \mathrm{p}<0.1$. Bootstrapped standard errors in parentheses. The number of observations diminishes so as to progressively eliminate possible dependent-variable outliers. In column 1 , one observation, for which the onion price was 17 or greater, was dropped; in column 2 four observations, for which the onion price was 12 or greater, were dropped; and in column 3, one observation, for which the onion price was 11.5 or greater, was dropped. 